\title{
Fungal Contamination Of Non-Cellulosic Instruments In Umuahia, Abia State, Nigeria.
}

\author{
Mbajiuka Chinedu Stanley ${ }^{1}$,Obeagu Emmanuel Ifeanyi ${ }^{2}$,Ifediora A.C. ${ }^{1}$ \\ 1.Lecturer, Department of Microbiology, Michael Okpara University of Agriculture,Umudike, Abia State, \\ Nigeria. \\ 2.Diagnostic Laboratory Unit, Department of University Health Services, Michael Okpara University of \\ Agriculture,Umudike, Abia State, Nigeria.
}

\begin{abstract}
A study of fungal contaminants of non-cellulosic instruments in Umuahia. Abia State was carried out. The instruments involved were microscopes, cameras, clocks and wristwatches.Four species of fungi were

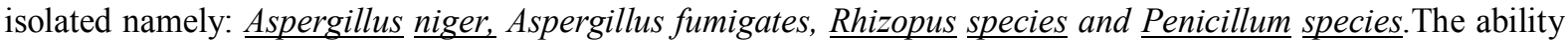
of these isolates to produce four enzymes namely cellulose, amylase, caseinase and gelatinase were tested. Among the isolates Aspergillus fumigates produced the highest amount of amylase and cellulose. All the isolates tested positive for caseinase and gelatinase production tests. Carbon sources such as glucose, sucrose, fructose, lactose, mannose and maltose were all utilized by the isolates as carbon sources, but Aspergillus niger utilized them faster than others. No gas was produced of these isolates ranged between $30^{\circ} \mathrm{C}$ and $37^{\circ} \mathrm{C}$. Aspergillus niger grew best at $32^{\circ} \mathrm{C}$, Aspergillus fumigates grew best at $32^{\circ} \mathrm{C}$, Aspergillus and penicillium species grew best at $30^{\circ} \mathrm{C}$. The determinantion of moisture contents at the isolates revealed that moisture (\% wet weight) of Aspergillus niger was $51.85 \%$, Aspergillus fumigates was $59.26 \%$, Rhizopus species was $72.59 \%$ while Penicillium species was $54.82 \%$. optimal $\mathrm{pH}$ determination indicated that $\underline{A}$. niger and $\underline{A}$. fumigates grew best at $\mathrm{pH} 4$, Rhizopus species grew best at $\mathrm{pH} 6$ while Penicillum species grew best at $\mathrm{pH}$. These results obtained can provide a starting point for preventing biodegradation of these expensive non-cellulosic instruments.
\end{abstract}

Keywords: Fungal Contamination,Fungi and Non-cellulosic instruments.

\section{Introduction}

According to Deacon (2007), Fungi are non-photosynthetic organisms with cylindrical filaments or hyphae and well defined cell walls. They are essentially similar to green plants in being immotile and possessing cell walls, yet they differ significantly in lacking chlorophyll and hence cannot photosynthesize their own food from carbondioxide and water.

Fungi being non-photosynthetic organisms possess extracellular hydrolytic enzymes which makes them suitable to live as saprophytes. Their ability to decompose organic matter leads to destruction of food, textiles, plastics, leathers and some other "unlikely" substances (Barron, 1977). Fungi cause a lot of plant and animal diseases including those of man (Berger et al., 1998). In short any fungi that is capable of growing at $37^{\circ} \mathrm{C}$ (Man's body temperature) must for the time being be regarded as a potential pathogen of man and other vertebrates (Alexopoulos et al., 1996).

Fungi are both destructive and beneficial in agriculture. In one hand, they are responsible for millions of dollars worth of damage to crops by causing a lot of plant diseases while in the other hand, they help in the degradation of organic matters and sub sequential release of mineral elements (recycling of essential elements in the soil), thus increasing the fertility of the soil for utilization by green plants (Webster and Weber, 2007).

Many industrial processes involving fermentation are made possible by fungi. Fungi are also used in the commercial production of single cell proteins, produced commercially are widely employed in food technology (Smith and Berry, 1975). The fact that the fungal enzymes are suitable for wine production (Nyiri, 1969).

Fungi also cause a lot ofdbiodegradation and biodeterioration of natural and artificial products by dissimilating objectionable chemical substances unto them. For example, they possess acids and enzymes which they release unto materials on which they are growing (Nyiri,1969). They act both on cellulosic and noncellulosic materials.

According to (Eggins and Allsopp, 1975), cellulosic material attacks by fungi appear to be the most familiar and widely recognized form of biodeterioration. The method and extent to which a cellulosic material is attacked by fungi depends on several factors in addition to those which apply to organisms generally such as $\mathrm{pH}$, humidity, temperature and availability of micronutrients (Eggins and Allsopp, 1975).

Apart from cellulosic materials, fungi attack a wide range of materials of diverse chemical composition (Non-cellulosic materials). The number and variety of non-cellulosic materials attacked are much smaller than that of the cellulosic materials (Eggins and Allsopp, 1975). 
Non-cellulosic materials includes plastics, glass and glass surfaces, electrical equipment, fuel, paints and paint films, glue, drugs, cosmetics and stones. Non-cellulosic material such as glasses is not utilized by fungi as a nutrient source but they are still prone to fungal attack. The fungi isolated from these materials include Phoma, Aspergillus, Penicillum, Acremoniella, Alternaria, Chaetomium, Stachybotrys, stemphyllium, Trichoderma and illocladium .

Non-cellulosic materials such as microscopes, cameras, watches and clocks seem to be most unlikely if not impossible materials to be attacked because they pose high resistance to microbial attack. They create unfavourable conditions of growth such as low relative humidity and non-availability of nutrients. Damages are caused by growth of fungi living on accumulations of dirty on these materials. This growth either obscures vision by their presence or more seriously by etching the lens surfaces by corrosive secretions. These fungi's abilities such as low food and moisture requirements make them grow on such unlikely surfaces. Such instruments when stored in moist warm areas can be ruined by fungi particularly those at Aspergillus and Penicillium species.

Climatic factors such as temperature, rainfall and wind can also affect the extent and nature of any deterioration or biodegradation.

This research work was aimed at isolating some fungal contaminants of some non-cellulosic materials in Umuahia and investigating the enzymes present in them and some conditions conducive for their survival in such unlikely materials.

\section{Materials And Methods}

\section{Materials}

\section{Sources of Fungal isolates}

All the isolates used in this work were all isolated from non-cellulosic materials like microscopes, cameras, clocks and watches gotten from Umuahia town.

\section{Reagents}

All reagents, media and other materials were gotten from the laboratories of microbiology, bio chemistry and chemistry departments at Michael Okpara University of Agriculture, Umudike. Abia-State.

\section{Methods}

\section{Isolation of fungal contaminants}

Non-celllulosic material used for this work includes microscopes (50 samples), cameras (50 samples), clocks (50 samples) and wrist watches (50 samples). These were obtained by random sampling from many microscopes, cameras, clocks and wrist watches from repairers and medical laboratories in Umuahia town.

The method employed for isolation was that of using sterile swabs dipped in sterile distilled water were used to clean the undersurfaces of glasses of wristwatches and clocks, and lens of cameras and microscopes. The swab was than streaked on sabourand dextrose agar (SDA) for the primary isolation. Subculture was then made from the primary plates onto different media. Pure cultures of the isolates were obtained by subsequent sub culturing. Slants were prepared in McCartney bottles for storage.

\section{Characterization and Identification of Isolates}

Characterization was done by macroscopic and microscopic examination of the isolates. Macroscopic examination was done by visual observation to ascertain the colour and growth patterns of the isolates. Microscopic examination was done by staining smear of isolates with lactophenol in cotton blue and examining them with different magnification on the microscope.

\section{Test for enzyme production by the Isolates}

\section{Cellulose test}

Filterpaper wads of Whatman No. 1 were oven-dried, weighed and placed in $250 \mathrm{ml}$ conical flasks with $40 \mathrm{mls}$ of cellulose medium in each. Each flask was inoculated with a mycelia disc cut off from the cultures of the isolates using cork borer. They were incubated for 10 days at $30^{\circ} \mathrm{C}$. The filter papers were removed and oven-dried at $60^{\circ} \mathrm{C}$ for one hour in tared aluminium dishes and reweighed.

The percentage loss in dry weight was then calculated as:

$$
\frac{\text { Difference in weight }}{\text { Initial dry weight }} \times \frac{100}{1}
$$

\section{Amylase test}

$0.2 \%$ soluble starch was incorporated into starch medium. $10 \mathrm{~mm}$ filter paper discs were prepared and dipped into both cultures of the isolates and placed on plates at $30^{\circ} \mathrm{C}$ for $24-48$ hours. They were then flooded with half strength Lugol's iodine. The plates were observed for decolorization of the starch iodine complex indicating amylase activity. The diameters of the zone of clearing were measured. 


\section{Caseinase test.}

Skimmed milk agar plates containing $0.4 \%$ skimmed milk were inoculated and incubated at $30^{\circ} \mathrm{C}$ for 3 days. The plates were observed for zone of cleatance after flooding with acid mercuric chloride solution.

\section{Gelatinase test}

A stab culture was made on gelatin medium. This was incubated at $300 \mathrm{C}$ for 3 days. Liquefaction was tested for by removing the cultures from the incubator and holding them at $40 \mathrm{C}$ for one hour. The tubes with liquefied gelatin indicated positive results.

\section{Utilization of Carbon Sources by the Isolate}

Peptone water was prepared and distributed into test tubes in $5 \mathrm{mls}$ amounts. Phenol red $(0.2 \%)$ solution $(\mathrm{pH} 4.8$ - 6.6) was added into each tube Durham's tubes were inverted into the test tubes and these were autoclaved at $121{ }^{\circ} \mathrm{C}$ for 15 minutes. $1 \%$ each of the carbon sources, Viz: Glucose, sucrose, fructose, lactose, mannose and maltose were sterilized separately by filtration and $1 \mathrm{ml}$ amount of each sugar was added to a test tube. The growth and fermentation of the sugars denoted by colour change from red to yellow (acid production) and by gas in the Durham's tubes was noted. One tube with only the base medium was incubated as control.

\section{Determination of Moisture content of Isolates}

$270 \mathrm{mg}$ of the isolates were obtained from the culture isolate and weighed into porcelain dishes and covered with porcelain covers. The dishes and their contents were placed in the oven at $70^{\circ} \mathrm{C}$ for 24 hours. The dishes and their contents were placed in the oven at $70^{\circ} \mathrm{C}$ for 24 hours. The dishes and their contents were cooled in a desiccators containing concentrated sulphuric acid as a drying agent and reweighed. Moisture content was calculated as moisture.

\section{$(\%$ wet weight $)=\frac{\text { loss in weight on drying }}{\text { Initial weight of sample }} \frac{100}{1}$}

\section{Determination of optimum growth temperature of the Isolates}

Conical flasks each containing $40 \mathrm{mls}$ of yeast extract both were inoculated with mycelia discs of the isolates. The flasks were incubated at different temperatures: $25^{\circ} \mathrm{C}, 30^{\circ} \mathrm{C}, 34^{\circ} \mathrm{C}, 37^{\circ} \mathrm{C}$ and $44^{\circ} \mathrm{C}$ for 5 days. The mycelia dry weight was determined by filtering the medium through pre-weighed Whatman filter paper No. 1 . The filter paper containing the mycelium was dried at $70^{\circ} \mathrm{C}$ for 1 hour and the final mycelia dry weight determined.

\section{Optimal pH determination}

The $\mathrm{pH}$ of the yeast extract both in conical flasks was adjusted to $\mathrm{pH} 2,3,4,5,6,7$ and 8 . The conical flasks were then inoculated with mycelia discs cut out from a profused growth of isolates with cork borer (size 2 ) and incubated for a period of 2 days at $300 \mathrm{C}$. At the end of incubation, the final $\mathrm{pH}$ of the media was taken, the contents filtered and weighed.

\section{Results}

Mycelia growth was observed on all the plates cultures incubated at 300C after 24 hours. The mycelia which appeared first in all the plates were white, but at maturity the different characteristic colour of each isolates were observed. From the pure cultures obtained, microscopic and macroscopic examinations of the isolates were shown in table 1 . Rhizopus species grow very rapidly within 48 hours while Penicilum species grew very sparsely on the plate. The slide preparation of the four isolates are shown on Figures 1, 2, 3 and 4.

\section{Production of enzymes by the isolates}

Table 2 shows the production of enzymes by the isolates. It was noticed that Penicillium noctadan and Aspergillus niger produced more cellulose enzyme than the other isolates. Rhizopus species produced the least. Amylase was produced most in Rhizopus species and Aspergillus niger with $18.5 \mathrm{~mm}$ and $18 \mathrm{~mm}$ respectively. While Aspergillus fumigates and penicillum noctadum produced less with $16 \mathrm{~mm}$ and $15 \mathrm{~mm}$ respectively. All the isolates were positive for caseinase enzyme test because zone of clearance were observed on all the skimmed milk agar plates inoculated with the isolates. Rhizopus species had a wider zone at clearance than the rest. With respect to gelatin liquefaction, all the isolates liquefied the nutrient gelatin with Aspergillus species being faster than the other isolates.

\section{Utilization of carbon sources by the isolates}

Table 3 shows the utilization of carbon sources by the isolates in liquid medium. It was observed that during the utilization of carbon sources, that all the test tubes except the control tubes turned from red to yellow indicating acid production but no gas was collected in the Durhman tubes as opposed to acid and gas production in normal fermentation.

\section{Moisture Content determination}

It was observed that the moisture content of Aspergillus niger determined by percentage wet weight was 51.\%; Aspergillus fumigates had a moisture content of 59.26\%, while Rhizopus species and Penicillium 
notacllum had moisture content of $72.59 \%$ and $54.82 \%$ respectively. From this result, Aspergillus niger had the lowest moisture content.

\section{Effect of Temperature on mycelia growth of the Isolates.}

Growth was observed in all the flasks incubated for 5 days. Figure V shows the relationship between growth in terms of mycelia weight and temperature Aspergillus niger showed optimum growth at $34^{\circ} \mathrm{C}$ while the optimum of Rhizopus species and Penicillium noctadum were both at $30^{\circ} \mathrm{C}$. The optimum of Aspergillus fumigates was $37^{\circ} \mathrm{C}$. The optimum temperature $30^{\circ} \mathrm{C}$ and $37^{\circ} \mathrm{C}$ indicating that all the isolates as being mesophilic fungi. But since Aspergillus fumigatus and Aspergillus niger were able to grow at temperature above $37^{\circ} \mathrm{C}$, they are regarded as thermotolerant fungi.

\section{Effect of PH of the isolates.}

Figure VI shows the effect of $\mathrm{pH}$ of incubation on mycelia growth of the isolates. From the figure, it can be seen that the optimum $\mathrm{pH}$ of growth for Aspergillus niger and Aspergillus fumigates was 4. Penicillum noctadim had an optimum $\mathrm{pH}$ at 5 while $\mathrm{pH} 6$ was optimum for Rhizopus species. All the isolates grow within the $\mathrm{pH}$ range of 2 to 8 .

Table 1: The Characterization of the isolates

\begin{tabular}{|c|c|c|c|c|c|}
\hline $\mathbf{S} / \mathbf{N}$ & Characteristics & Aspergillus niger & $\begin{array}{l}\text { Aspergillus } \\
\text { fumigates }\end{array}$ & Rhizopus species & Penicillium noctadium \\
\hline 1 & $\begin{array}{l}\text { Colour and nature } \\
\text { of mycelia on plates }\end{array}$ & $\begin{array}{l}\text { It grows white } \\
\text { initially but turns } \\
\text { dark brown at } \\
\text { maturity. }\end{array}$ & $\begin{array}{l}\text { It grows by spreading } \\
\text { producing grayish } \\
\text { green, mycelia at } \\
\text { maturity. }\end{array}$ & $\begin{array}{l}\text { It grows very rapidly, } \\
\text { produing white cotto- } \\
\text { like mycelia that } \\
\text { grew to the brim of } \\
\text { the plate within } 48 \\
\text { hours. At maturity, it } \\
\text { produces dark spores. }\end{array}$ & $\begin{array}{l}\text { It initially grows as yellow } \\
\text { spots colonies and turns } \\
\text { green at maturity. }\end{array}$ \\
\hline 3 & $\begin{array}{l}\text { Spores colour and } \\
\text { maturity }\end{array}$ & $\begin{array}{l}\text { Conidia are spiny } \\
\text { and dark brown in } \\
\text { colour. }\end{array}$ & $\begin{array}{l}\text { Conidia are round } \\
\text { and grayish green in } \\
\text { colour. }\end{array}$ & $\begin{array}{l}\text { Spores are spherical } \\
\text { in shape, tiny and } \\
\text { dark in colour. }\end{array}$ & $\begin{array}{l}\text { Conidia are spherical and } \\
\text { smooth and are greenish in } \\
\text { colour }\end{array}$ \\
\hline 4 & Hyphae & Septate & Septate & Unseptate & Septate \\
\hline
\end{tabular}

Table 2: Production of enzymes by the isolates

\begin{tabular}{|l|l|l|l|l|}
\hline Enzymes tested & Aspergillus niger & Aspergillus fumigates & $\underline{\text { Rhizopus species }}$ & $\underline{\text { Penicilluim noctadum }}$ \\
\hline Cellulose & +++ & +++ & + & ++ \\
\hline $\begin{array}{l}\text { Amylase } \\
*\end{array}$ & +++ & ++ & +++ & ++ \\
\hline Caseinase & $+18 \mathrm{~mm}$ & & & + \\
\hline Gelatinase & ++ & + & ++ & + \\
\hline
\end{tabular}

+ Slight enzyme production

$++\longrightarrow$ Moderate enzyme production

Very good enzyme production

Approximate measurement in diameter $(\mathrm{mm})$ of zone of clearing in Amylase production.

Table 3: Utilization of carbon sources by the Isolates

\begin{tabular}{|l|l|l|l|l|}
\hline Carbon Sources & Aspergillus niger & Aspergillus fumigates & Rhizopus species & Penicilluim noctadum \\
\hline Glucose & A & A & A & A \\
\hline Fructose & A & A & A & A \\
\hline Lactose & A & A & A & A \\
\hline Sucrose & A & A & A & A \\
\hline Maltose & A & A & A & A \\
\hline Mannose & A & A & A \\
\hline
\end{tabular}




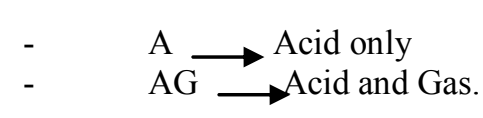

\section{Discussion}

In this project, Aspergillus niger, Aspergillus fumigates, Rhizopus species and Penicillium species were the main contaminants isolated from wristwatches, clocks and cameras in Calabar Municipality in Nigeria.

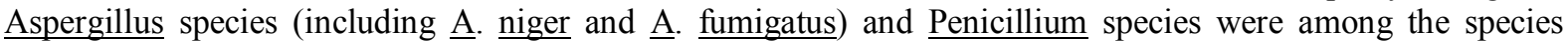
which have been similarly reported as being amongst the major contaminants of instruments with glasses, Nagamuttu (1967). Rhisopus species was not isolated in his survey. This might be as a result of differences in geographical and climatic conditions. Eggins and Allsopp (1975) contended that biodeterioration losses are much more serious in developing countries particularly in the tropics, so this might cause those instruments used in this work to be more prone to fungi than those isolated by Nagamuttu (1967).

More isolates were obtained from wristwatches than other instruments. This might be because there is always possibility of increased contact with moisture.

The result of cellulose test indicated that all the isolates produced cellulose enzyme. The fact that there was a loss in weight due to mycelia production was a pointer to this ability. Among the isolates, Aspergillus species produced more cellulose (Table 2). This conforms to the definition of these organisms as very active decomposers (Siu, 1951). Rhizopus species and Penicillium species were included among slow decomposers. This enzyme helps the organisms to degrade dirts that accumulate on the instruments.

The results of the Amylase test on the isolates as shown in table 2 indicated that Rhizopus had the highest amylolytic activity, seconded by Aspergillus niger. This no doubt confirms to their use for the production of amylase enzyme commercially (Smith and Berry, 1975). Aspergillus fumigates and penicillium species produces amylase enzyme but in a quantity that is of no industrial importance. The presence of the enzyme amylase helps the isolates to digest polysaccharides (starch) found among the accumulated dirts found on the instruments they attack.

Caseinase test carried out on the isolates showed that all the isolates have the enzyme caseinase which helps in the digestion of casein if present among the substances accumulated with the dirts surrounding and inside the instruments.

All the isolates tested positive in the gelatinase test carried out on the isolates and therefore indicates the possession of the enzyme gelatinase.

The presence of these two enzymes in all the isolates showed that they can digest protelytic materials found among the dirts accumulated on the instruments they colonize. The isolates can be said to possess the protease enzyme. Aspergillus and Rhizopus species were confirmed to possess proteases by Smith and Berry (1975). Species of Aspergillus, Rhizopus and Penicillium were cited as suitable for protease production industrially (Beuchat, 1978). This indicates the possession of proteases enzyme by the isolates.

The ability of the isolates to utilize some carbon sources by producing acid and gas was tested (table 3 ). Out of the (6) sugars tested, all the isolates produced acid but no gas. This is probable because fungal cells are well buffered as little changes are reported in the endogenous respiration. Aspergillus niger grow well in Glucose sucrose, mattose, mannose and had poor growth on medium containing lactose or fructose. Aspergillus fumigatus and Rhizopus species grew well in glucose and sucrose, but had poor growth in other carbon sources used. Penicillium species grow well in all the carbon sources except in mannose where they had poor growth. This confirms the use of Aspergillus species, Rhizopus species and Penicillium species in the industrial production of gluconic acid, lactic and citric acid (Smith and Berry 1975).

The result of the effect of temperature on the growth of the isolates shown on figure (5) indicated that they were all mesophilic with a range of $30^{\circ}-37^{\circ} \mathrm{C}$. This conforms to the definition of mesophiles given by Sharp (1978) as those that grow best at $20^{\circ} \mathrm{C}$ to $40^{\circ} \mathrm{C}$. Aspergillus species grew even at temperature range of $37^{\circ} \mathrm{C}$ to $44^{\circ} \mathrm{C}$ and thus can be said to be thermotolerant in the sense of Levine and Cooney (1973) who used the term for yeast able to grow above body temperature $\left(370-40^{\circ} \mathrm{C}\right)$. This enables Apergillus species to survive on these instruments even when temperature of environment rises. Rhizopus species and Penicillium species were unable to grow at $44^{\circ} \mathrm{C}$. Their optimum temperature was $30^{\circ} \mathrm{C}$ while Aspergillus niger and Aspergillus fumigatus grow at the optimum temperatures of $34^{\circ} \mathrm{C}$ and $37^{\circ} \mathrm{C}$ respectively.

The results of the optimal $\mathrm{pH}$ determination of the isolates shown in figure (6) showed that the Aspergillus niger and Aspergillus fumigatus have their optimal $\mathrm{pH}$ at $\mathrm{pH} 4$ while Rhizopus species and Penicillium species grew best at $\mathrm{pH} 6$ and $\mathrm{pH} 5$ respectively. They all grew within the ranges of $\mathrm{pH}$ used (that is $\mathrm{pH}$ range of 2 to 8 ). Ingold (1962) reported that most fungi grow over a wide range of $\mathrm{pH}$ (below 3 to $8 \mathrm{ABD}$ above).

In the $\mathrm{pH}$ determination, there were fluctuations in $\mathrm{pH}$ before incubation and $\mathrm{pH}$ after incubation. This may be because $\mathrm{pH}$ rarely remain constant during growth of the fungi, but tends to shift considerably even if the medium was well buffered (Ingold, 1962). 
This variation did not seem to affect the growth of the fungi under investigation usually because they grow over a wide range of PH. The growth of Rhizopus species at low pH was minute, although (Smith and Berry, 1975) noticed that the members of mucorales lack the ability to grow at low PH. The reason for their growth might be because of the fluctuation of $\mathrm{pH}$ in fungal growth. Penicillium and Aspergillus species were said to be able to grow at low $\mathrm{pH}$ values of between $\mathrm{pH} 0$ and $\mathrm{pH} 2$ (William and Spicer, 1957).

Water is a vital commodity for all metabolic activities in living organisms. Water must be therefore present either in the air surrounding the material or in the material itself before fungi can act on it. The water content of a material will affect its susceptibility to biodeterioration and biodegradation. The lower the moisture content of a product, the less liable it is to support microbial growth (Ayerst, 1969). In the determination of moisture content of the isolates, it was found out that Rhizopus species has moisture (\% wet weight) of $54.82 \%$ while Aspergillus niger and Aspergillus fumigatus have moisture of $51.85 \%$ and $59.26 \%$ respectively. Usually the fungi requires a film of water around the hyphae for growth to occur, however some fungi have been noted to grow mycelially at relative humidity well below that of other microbes (Ayerst, 1969). Moisture content in equilibrium of $70 \%$ or more as in Ahizopus species supports heavy growth. But there are some fungi which can grow at lower relative humilities such as below $60 \%$. Aspergillus niger, Aspergillus fumigatus and Penicillium species fall under these fungi (Ayerst, 1969).

Low moisture content of Aspergillus niger and Penicillium species shows that they can survive dry environment.

\section{Conclusion}

The fungi isolated from contaminants of instruments (Clocks, wristwatches and cameras) from Calabar Municipality, were characterized and identified as being in two classes namely Zygomycetes (Rhizopus species) and Ascomycetes (Aspergillus species and Penicillium speceis).

All the isolates tested positive for cellulose, amylase, caseinase and Gelatinase production. These enzymes help the organisms to degrade dirts that accumulate on the instruments.

In the test for utilization of carbon sources by these isolates, out of the (6) sugar tested (sucrose, lactose, glucose, maltose, fructose and mannose), all the isolates produced acids but no gas in all the media used.

Effect of temperature on mycelia growth of the isolates showed that Aspergillus niger grow in the temperature range of $25^{\circ} \mathrm{C}$ to $44^{\circ} \mathrm{C}$ with optimum at $34^{\circ} \mathrm{C}$. Aspergillus fumigatus grow in the temperature range of $25^{\circ} \mathrm{C}$ to $44^{\circ} \mathrm{C}$ with an optimum at $37^{\circ} \mathrm{C}$. Rhizopus and Penicillium species both grow in the temperature range of $25^{\circ} \mathrm{C}$ to $37^{\circ} \mathrm{C}$ with optimum at $30^{\circ} \mathrm{C}$.

$\mathrm{PH}$ determination revealed that Aspergillus niger and Aspergillus fumigatus had an optimum of $\mathrm{pH} 4$ while Penicillium and Rhizopus had optimum of $\mathrm{pH} 5$ and $\mathrm{pH} 6$ respectively.

Moisture content of Rhizopus was $72.59 \%$. While Aspergillus niger was $51.85 \%$; Aspergillus fumigatus $59.26 \%$ and Penicillium $54.82 \%$. Therefore, they can survive dry conditions.

Since humid condition is necessary for the growth of fungi on instruments of unlikely nature, the menance of fungal deterioration could be reduced to the bearest minimum if the humidity of these instruments is maintained at a level unfavourable for these isolates. Regular removal of dirts from these instruments should be encouraged as it will go a long way in preventing the growth of these fungi as the dirts which is their source of nutrients will no more be there.

There is need for many more researches in this field to be carried out as little has been done in this field at present.

Investigation should be carried out to ascertain the mechanism and agents responsible for deterioration of these instruments that is enzymes, acids or any other substance produced which does the harm.

With the knowledge of all these, the deterioration of instruments by fungi can be minimized.

\section{References}

[1]. Alexopoulos, C. J. (1962): Introduction to Mycology. Pp. 3 - 44. John Wiley and sons Inc., New York.

[2]. Ayerst, G. (1969): The effects of moisture and temperature on growth and spore germination in some fungi. Journal of Stored Products Research 5 (2), 127 - 141.

[3]. Beuchat, L. R. (1978): Food and beverage mycology. Pp 378 - 388. Avi Publishing Company Inc. Connecticut.

[4]. Eggins, H. O. W. and Allsopp, D. (1975): Biodeterioration and biodegradation by fungi. In smith, E. J. and Berry, D. R. The filamentous fungi I: $301-324$

[5]. Ingold, C. T. (1962): The biology of fungi, pp 35 - 42. Hutchinson Educational, London.

[6]. Nagamuttu, S. (1967): Moulds on optical glass and control measures. International Biodeterioration Bulletin $3(1)$ : $25-30$.

[7]. Nyiri, L. (1969): M anufacture of pectinases, Part II. Process Biochemistry 4(8): $27-30$.

[8]. Sharp, R. F. (1978): Investigative Mycology. Heinemann Educational Books Ltd. London.

[9]. Siu, R. G. H. (1951): Microbial decomposition of Cellulose pp 531 - 563. Reinhold Publ. New York.

[10]. Smith, J. E. and Berry, D. R. (1975): The Filamentous fungi, I: $140-209$.

[11]. William, R. E. O. and Spicer, C. C. eds. (1957): Microbial Ecology. 7th Symp, of Soc. Gen Microbiol; Cambridge Press, Cambridge.

[12]. Barron,G.L.(1977).The Nematode-Destroying Fungi.Canadian Biological Publications, Guelph,ON. 
[13]. Berger,L.R.,Speare,P.,Daszak,D.E.,Green,A.A.,Cunningham,C.L.,Goggin,R.,et al.(1998).Chytridiomycosis Causes Amphibian Mortality Associated with Population Declines in the Rain Forests of Australia and Central America.Proceedings of the National Academy of Sciences USA 95:9031-9036.

[14]. Alexopoulos,C.J.,Mims,C.W.and Blackwell,M.(1996).Introductory Mycology $4^{\text {th }}$ Edition.John Wiley and Sons Inc.,New York.

[15]. Deacon,J.(2006).Fungal Biology, $4^{\text {th }}$ ed.Blackwell Publishing,Malden,M.A.

[16]. Webster,J. And Weber,R.W.S.(2007).Introduction to Fungi.Cambridge University Press,New York. 